\title{
ARSITEKTUR JAWA PADA WUJUD BENTUK DAN RUANG MASJID AGUNG SURAKARTA
}

\author{
Dewi Adityaningrum \\ Magister Arsitektur Universitas Sebelas \\ Maret Surakarta \\ e-mail: dewiaditya83@gmail.com

\section{Titis Srimuda Pitana} \\ Magister Arsitektur Universitas Sebelas \\ Maret Surakarta \\ e-mail: titissrimuda@staff.uns.ac.id \\ Wiwik Setyaningsih \\ Magister Arsitektur Universitas Sebelas \\ Maret Surakarta \\ e-mail: wiwikhermono@gmail.com
}

\begin{abstract}
ABSTRAK
Budaya tradisi memiliki estetika tersendiri. Arsitektur tradisional Jawa memiliki nilai estetika tersendiri yang merupakan manifestasi dari cara orang Jawa hidup dalam menanggapi lingkungan. Joglo sebagai bangunan arsitektur Jawa merupakan representasi simbolis dari realitas yang nilainya telah melampaui bentuk dan struktur bangunan. Masjid Agung Surakarta adalah masjid yang berkaitan dengan masuknya Islam di tanah Jawa. Pengaruh dari nilai-nilai lokal menjadikan masjid tersebut memiliki nilai-nilai arsitektur Jawa. Penelitian ini menggunakan metode kualitatif deskriptif yang bertujuan mengetahui wujud representasi Arsitektur Jawa dan menemukan unsurunsur yang memuat nilai-nilai kehidupan masyarakat Jawa pada Masjid Agung Surakarta, sehingga nilai-nilai dari kehidupan masyarakat Jawa tersebut juga berimbas pada masjid Jawa lainnya yang mengambil prototipe dari masjid ini. Hasil penelitian menunjukkan bahwa terdapat unsur-unsur pada Masjid Agung Surakarta yang mengadopsi nilai-nilai budaya dan arsitektur Jawa. Berbagai elemen pembentuk masjid yang berkaitan erat dengan apa yang ada pada arsitektur Jawa, yaitu atap tajug yang menjadi penanda tipe masjid Jawa adalah unsur bentuk yang paling dominan, ruang dalem dan pendopo, soko guru, atap tajug tumpang tiga dan atap limasan, serta pajupat dan pancer.
\end{abstract}

KATA KUNCI: Arsitektur Tradisional Jawa, Masjid Agung Surakarta, Masjid di Jawa

\section{PENDAHULUAN}

Arsitektur tradisional Jawa memiliki nilai estetika tersendiri yang merupakan manifestasi dari cara orang Jawa hidup dalam menanggapi lingkungan. Joglo sebagai bangunan arsitektur Jawa merupakan representasi simbolis dari realitas yang nilainya telah melampaui bentuk dan struktur bangunan. Joglo dalam bahasa Jawa yang berarti untuk menjalin komunikasi dengan Allah baik secara vertikal maupun horizontal dengan alam lain dan lingkungan. Arsitektur rumah joglo adalah salah satu bentuk perwujudan estetika tradisi Jawa. Arsitektur rumah joglo tersusun atas struktur luar yang kasat mata dan struktur dalam yang tersembunyi, keduanya bertalian satu sarna lain. Relasi antar struktur rumah tradisional Jawa menggambarkan kedalaman makna. Makna tersebut dibangun dan dijiwai oleh kultur setempat dengan senantiasa dilandasi suatu nilai yang dijunjung tinggi, yang kemudian dinilai sebagai simbol kebudayaannya.

Arsitektur Jawa sangat lazim diposisikan sebagai arsitektur tradisional karena harus berhadapan dengan arsitektur modern. Ruang kesadaran manusia Jawa yang menempatkan kearifan lokal menjadi bagian penting dalam membangun identitas arsitektur
Jawa, sehingga menjadikan arsitektur Jawa berkembang menurut metafisikanya sendiri dan memiliki filosofi yang berbeda dengan arsitektur lainnya. Sebagai realitas ciptaan, arsitektur Jawa merupakan karya masterpiece, adiluhung, dan sophisticated jika dipandang dari aspek filosofis, kaidah-kaidah keseimbangan antara fungsi dan konstruksi, klimatologi, kepadatan pengguna dan area, komposisi bahan, proporsi, tampilan, garis tegas ornamen, sampai makna warna. Hal ini menunjukkan bahwa arsitektur Jawa menjadi produk kebudayaan yang sarat akan kearifan lokal. Hal inilah yang menyebabkan arsitektur Jawa memiliki kemampuan berkomunikiasi melalui tanda grafis yang melekat padanya. Nilai simbolisme arsitektur Jawa terletak pada cara penyampaian makna dari wujud suatu bangunan yang mengandung bobot ekspresi dan bobot makna. Bobot ekspresi meliputi ruang dan tampilan permukaannya, sedangkan bobot makna adalah media yang berisi muatan atau pesan yang hendak disampaikan. Hal ini menunjukkan bahwa makna arsitektur Jawa lebih menekankan pada pembongkaran terhadap symbol, karena simbol merupakan penghantaran pemahaman terhadap objek untuk menerangkan makna yang dikandungnya. 


\section{TINJAUAN PUSTAKA}

\section{Masjid Jawa}

Masjid Jawa memiliki beberapa karakteristik menurut Pijper (1947) adalah sebagai berikut: (1) mempunyai bentuk persegi, (2) tidak disangga oleh tiang-tiang pada dasar bangunannya, (3) memiliki atap tumpang dua sampai lima tingkatan, (4) memiliki perluasan ruang pada sisi barat atau barat laut, yang digunakan sebagai mihrab, (5) memiliki serambi Masjid pada bagian depan atau samping, (6) h alaman sekeliling Masjid tertutup oleh dinding-dinding dengan hanya satu pintu masuk melalui sebuah gerbang di bagian depan.

Arismunandar $(2002$, p.88) menjelaskan bahwa Masjid Jawa memiliki denah yang terpusat, memiliki karakteristik atap tumpang dengan dua sampai tiga tingkatan, memiliki jumlah deret tiang yang mengelilingi bagian luar, memiliki serambi tambahan pada bagian depan bangunan, halaman berdinding, menara hingga makam pada bagian depan. Sedangkan menurut Budi (2006, p.220-231), ada tiga elemen dalam Masjid Jawa, yaitu: (1) Ruang shalat sebagai kebutuhan mutlak yang digunakan jemaah untuk melakukan ibadah, (2) Mihrab merupakan ruang imam memimpin shalat, sekaligus sebagai penunjuk arah kiblat, (3) Atap dan struktur Masjid Jawa memiliki bentuk tumpang yang khas dimana pada bagian bawah terdapat struktur (sokoguru) yang menyangganya.

Tata spasial Masjid Jawa terdiri dari beberapa bagian yaitu, pintu gerbang, serambi, ruang shalat, mihrab, makam. Setiawan (2010, p.172) mengatakan bahwa keberadaan Masjid dan makam tidaklah dapat dipisahkan dan memiliki posisi yang khas antara keduanya. Dimana letak makam tokoh penting (sunanwali-kyai-pangeran-raja) berada bagian depan (arah kiblat) pada sebuah Masjid. Serambi dikaitkan dengan konsep habluminnannas dalam Islam, yaitu hubungan antar manusia dimana serambi sendiri juga bisa berfungsi sebagai ruang bersama yang mempertemukan jamaah yang ada di Masjid tersebut. Dalam Masjid Jawa, sokoguru menjadi semacam panutan pola pada ruang shalatnya dimana banyak Masjid Jawa menggunakan pakem ini.

Menurut Macrus (2008, p. 67) terdapat Sakarawa yaitu tiang yang berjumlah dua belas yang mengitari sokoguru. Mihrab pada Masjid Jawa merupakan ruang yang dibatasi oleh dinding, dengan skala proporsional untuk imam memimpin shalat. De Graaf mengajukan teori bahwa prototipe bangunan masjid Indonesia tidak berdasarkan atas bangunan yang ada di Indonesia, tetapi dari bentuk masjid-masjid yang ada di daerah Gujarat (India).
Susunan rumah tradisional Jawa, terbagi dalam dua komponen yang bersifat privat intim atau keramat (petanen) disebut dalem dan yang luar, yang berhubungan dengan masyarakat diberi nama pelataran atau njaba (ruang luar). Ruang yang bersifat keramat diwakili oleh dalem Ageng yang terdapat di pusat dalam tata susun ruang rumah tradisional Jawa. Adapun ruang luar yang diwakili oleh pendapa dan pelataran mempunyai sifat terbuka dan menerima. Pengertian antara wilayah dalam dan luar, antara keterbukaan bermasyarakat dan keintiman tertutup keluarga di sini memperoleh kesatuan yang harmonis, sehingga bukan pertentangan melainkan dialektika luar-dalam antara hidup pribadi dan kemasyarakatan tercapai sangat seimbang. Begitu pula penataan dalem yang sakral dan pendapa yang profan menunjukkan betapa serasi dialektik antara hubunganhubungan vertikal ke Tuhan dengan yang immanen, yang mengatasi dengan yang mendalami (Mangunwijaya, 1988, p. 111-113).

Bentuk simbolisme dalam arsitektur tradisional Jawa dapat dilihat pada tata susun atau struktur bangunannya. Struktur ruang rumah tradisional Jawa yang paling lengkap terdapat pada istana dan rumah pangeran yang merupakan strata pembesar kerajaan, yaitu menggunakan bentuk joglo.

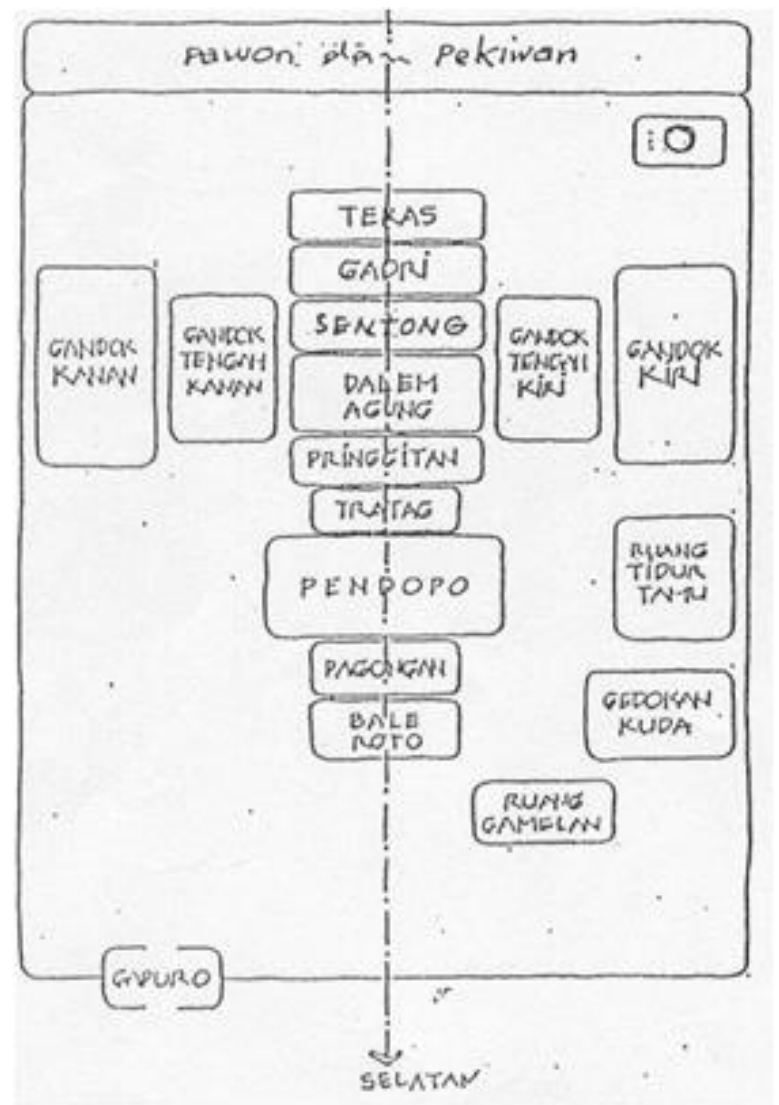

Gambar 1. Pola tata ruang dan tata bentuk rumah Jawa (Sumber: Pras, 2000)

\section{Arsitektur Tradisional Jawa}


Struktur ruang rumah bentuk joglo terdiri dari bangunan utama dan bangunan tambahan. Bangunan utama terdiri dari kuncungan, pendapa, pringgitan dan dalem ageng. Dalem Ageng terdiri dari beberapa ruang yaitu senthong tengen, senthong tengah dan senthong kiwo (Gambar 1).

Nilai keagungan dan kesakralan, rumah tradisional Jawa dihiasi dengan berbagai macam ornamen hias yang bersifat profan dan sakral. Hiasan diletakkan pada bagian-bagian struktur bangunan seperti tiang, blandar, dudur, ander, dhadhapeksi, sunduk, pemidangan, tebeng pintu, tebeng jendela, daun pintu, dan sebagainya. Hiasan-hiasan tersebut pada dasarnya ada dua macam, yaitu hiasan yang konstruksional dan hiasan yang tidak konstruksional (Dakung, 1982, p.123). Hiasan konstruksional adalah hiasan yang langsung dibuat pada bagian bangunan (diukirkan langsung pada bagian bangunan). Hiasan tidak konstruksional adalah hiasan yang dapat dilepas dari bangunannya dan tidak berpengaruh apa-apa terhadap konstruksi bangunannya.

\section{METODE PENELITIAN}

Penelitian ini menggunakan pendekatan deskriptif kualitatif. Penelitian kualitatif adalah metode penelitian yang berlandaskan pada filsafat postpositivisme, digunakan untuk meneliti pada kondisi objek yang alamiah dimana peneliti adalah sebagai instrumen kunci, pengambilann sampel sumber data dilakukan dengan cara purposive dan snowball, teknik pengumpulan dengan triangulasi, analisis data bersifat induktif, dan hasil penelitian kualitatif lebih menekankan makna daripada generalisasi (Sugiyono, 2017, p. 15). Pendekatan kualitatif ini diambil karena dalam penelitian ini sasaran atau objek penelitian dibatasi agar data-data yang diambil dapat digali sebanyak mungkin serta agar dalam penelitian ini tidak dimungkinkan adanya pelebaran objek penelitian. Penelitian dilakukan langsung di lapangan, rumusan masalah juga ditemukan di lapangan, kemungkinan data berubah-ubah sesuai data yang ada di lapangan, sehingga akan ditemukan sebuah teori baru di tengah lapangan. Penelitian ini bertolak dari cara berpikir induktif, kemudian berpikir secara deduktif, penelitian ini menganggap data adalah inspirasi teori.

Penelitian kualitatif menggunakan metode kualitatif yaitu pengamatan, wawancara, atau penelaahan dokumen. Metode kualitatif ini digunakan karena beberapa pertimbangan: 1) menyesuaikan metode kualitatif lebih mudah apabila berhadapan dengan kenyataan jamak, 2) metode ini menyajikan secara langsung hakikat hubungan antara peneliti dan responden, 3) metode ini lebih peka dan lebih dapat menyesuaikan diri dengan banyak penajaman pengaruh bersama terhadap pola-pola nilai yang dihadapi (Moleong, 2007, p.10).

Dalam penelitian kualitatif, peneliti melakukan penelitian dalam skala kecil, kelompok yang memiliki kekhususan, keunggulan, inovasi, atau bisa juga bermasalah. Kelompok yang diteliti merupakan satuan sosial budaya yang bersifat alamiah dan saling berinteraksi secara individual ataupun kelompok (Sukmadinata, 2009, p. 99).

Dari teori-teori di atas dapat ditarik simpulan bahwa penelitian deskriptif kualitatif menggunakan langkah-langkah penelitian dari pengamatan fenomena yang dapat dijelaskan secara terperinci dan ilmiah. Pengamatan ilmiah yang dimaksudkan adalah pengamatan yang dimulai dari hal-hal terkecil/ sempit ke hal-hal lebih besar/luas atau dengan kata lain penelitian ini dari bentuk induktif ke bentuk deduktif.

\section{HASIL PENELITIAN}

Unsur-unsur Islam sudah menjadi sinkretik dengan unsur-unsur arsitektur tradisional Jawa, sehingga makna yang terkandung dalam arsitektur Masjid Agung Surakarta menunjukkan adanya unsur-unsur Islam. Hal ini disebabkan bahwa Islam tidaklah membatasi bentuk, langgam, inovasi teknologi, ataupun pola tertentu, namun Islam memberikan prinsip dasar, kekuatan spiritual dan konsep pemersatu. Sebagai pengaruh dari akulturasi budaya Jawa, Masjid Agung Surakarta menjadi bagian dari arsitektur tradisional Jawa yang memberi manifestasi entitas masjid dengan menampilkan nilai-nilai kearifan lokal Jawa serta pemaknaan pada unsur-unsurnya baik itu pada wujud bentuk (bangunan fisik) maupun pada wujud ruang (spasial; ruang utama dan serambi) masjid.

\section{Bentuk Atap}

Atap Masjid Agung Surakarta terbagi menjadi dua jenis yaitu tajug tumpang tiga yang menaungi ruang utama masjid dan limasan yang menaungi ruang serambi masjid (Gambar 2). Bentuk atap tajug dengan model piramida mengerucut di satu titik puncak sejajar dengan keempat soko guru pada tengah ruang utama (ruang dalem dalam terminologi Jawa)

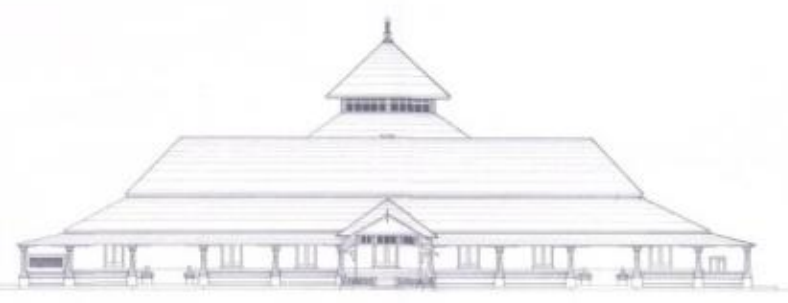

Gambar 2. Bentuk atap tajug Masjid Agung Surakarta (Sumber: Fakultas Teknik UNS, 2004) 
Banyak ditemukan nilai-nilai filosofis yang ditunjukkan oleh eksistensi dari atap tajug yang menjadi atap utama masjid dan merupakan bentuk yang paling dominan, yaitu;

1. Dengan bentuk atap tajug piramida berjenjang tiga semakin keatas semakin mengerucut/ mengecil, ada titik puncak atau pencapaian akhir yang disimbolkan dengan mahkota

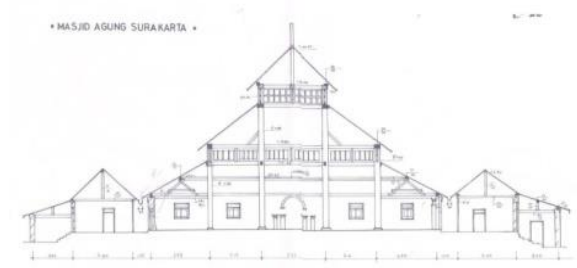

Gambar 3. Struktur atap tajug Masjid Agung Surakarta (Sumber: Fakultas Teknik UNS, 2004)

2. Vertikalitas bentuk atap tajug yang mengarah keatas, menggambarkan adanya unsur transenden/ immaterial berkenaan dengan pesan yang disampaikan, yaitu tujuan dari ibadah kepada Allah swt. Horizontalitas bentuk atap limasan yang disimbolkan dengan bubungan (molo), menggambarkan adanya unsur immanen/material berkenaan hubungan sesama manusia dan hubungan dengan lingkungannya

3. Bentuk penampang bawah atap tajug adalah bujursangkar, hal ini disebabkan oleh bentuk denah ruang utama yang juga berbentuk bujursangkar, demikian pula dengan atap limasan yang berpenampang persegi panjang, menaungi pola denah ruangnya yang persegi panjang. Dengan demikian, atap efektif menaungi ruangan secara proporsional sesuai dengan bentuk atau pola denahnya. Peran dari masing-masing atap sesuai dengan pola denahnya dan didukung pula oleh sifat ruang dan sakralitas bentuk atapnya

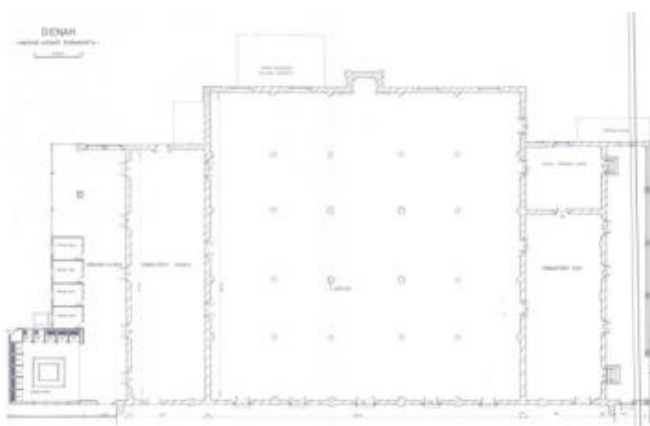

Gambar 4. Denah Masjid Agung Surakarta (Sumber: Fakultas Teknik UNS, 2004)

4. Atap tajug 1 yang paling atas, disokong oleh empat soko guru yang menjadi soko utama. Oleh karena itu dapat diketahui bahwasanya elemen yang pertama membentuk struktur dan konstruksi masjid adalah soko guru dan atap tajug 1. Kemudian soko pengarak dan atap tajug 2 atau tengah, karena pada ujung atap tajug 2 menempel pada soko guru, sedangkan bagian bawahnya disokong oleh soko pengarak. Terakhir soko pengarak dan atap tajug 3 atau paling bawah.

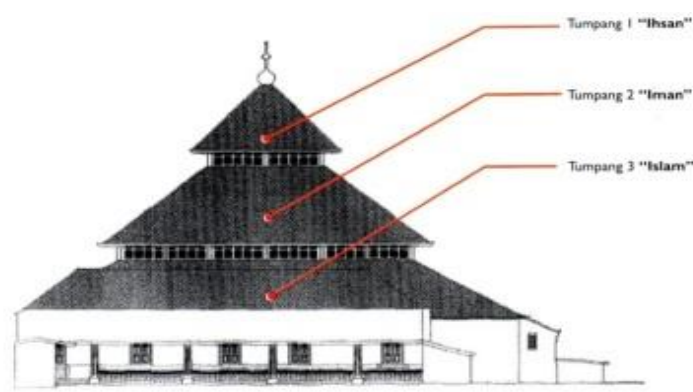

Gambar 5. Detail pembagian atap Masjid Agung Surakarta (Sumber: Fakultas Teknik UNS, 2004)

5. Atap tajug memanifestasikan konsep kosmologi diwujudkan dari empat soko guru yang melambangkan pajupat (empat penjuru mata angin) dan atap tajug dengan mahkota dan lampu gantung yang melambangkan pancer.

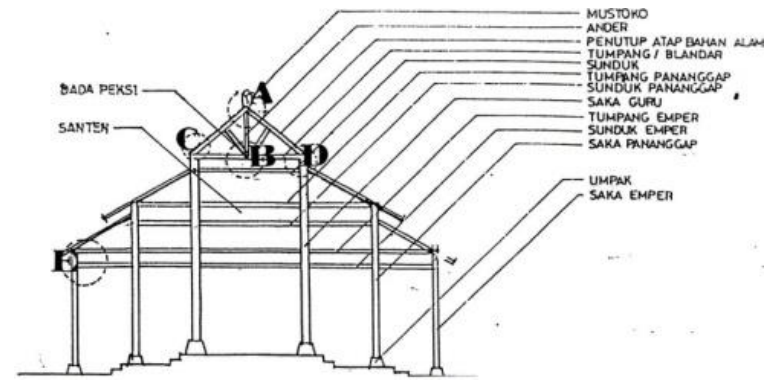

Gambar 6. Struktur rangka atap Masjid Agung Surakarta (Sumber: Fakultas Teknik UNS, 2004)

6. Keempat soko guru merupakan simbol empat kekuatan yang memiliki keseimbangan, sehingga mampu menyokong atap tajugnya, selain memberikan keserasian kekuatan bentuk dan hubungan antar elemen. Pancer dipancarkan melalui titik tengah atau poros yang disimbolkan dengan lampu gantung, secara vertikal segaris dengan mahkota pada titik puncak atap tajug, sehingga semua elemen yang terpancar dari manifestasi kosmologi Jawa pada wujud bentuk atap tajug, termasuk soko guru, mahkota dan lampu gantung yang memiliki keterkaitan kuat dengannya, menciptakan harmonisasi yang bermakna bahwa kesesuaian, keserasian, keseimbangan, dicapai dengan memadukan tiap elemen secara benar dan indah, berhubungan dan saling melengkapi membentuk satu kesatuan. Ini merupakan 
implementasi dari kosmologi Jawa yang berbunyi kiblat papat lima pancer atau pajupat dan pancer.

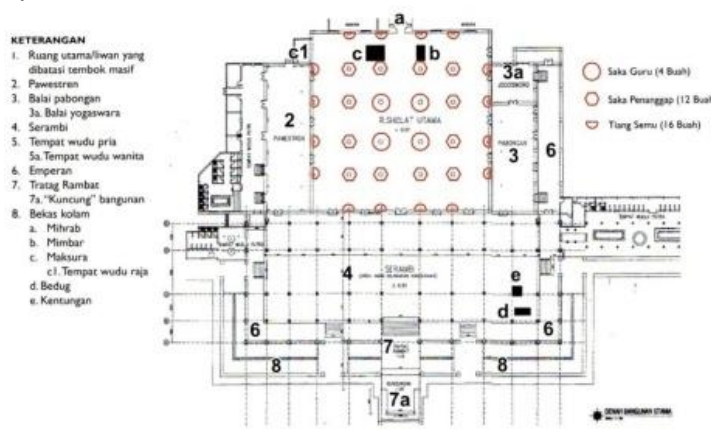

Gambar 7. Denah Masjid Agung Surakarta (Sumber: Fakultas Teknik UNS, 2004)

7. Dari dua jenis atap yaitu tajug dan limasan, hadirlah dualisme bentuk atap yang merupakan oposisi biner, dua hal yang berbeda tapi menjadi satu kesatuan. Sehingga terdapat acuan yang jelas berbeda yang membedakan satu dengan lainnya tetapi saling melengkapi dan memperkuat.

8. Atap tajug berjenjang tiga secara filosofis religius, mulai dari yang paling bawah ke atas, melambangkan makna; Islam- Iman - Ihsan. Pemaknaan terhadap tiap jenjang atap tajug tersebut didasari oleh Hadits Jibril dalam HR. Muslim no.8. Sehingga pancaran ide yang disimbolkan oleh ketiga jenjang atap tajug masjid tersebut memiliki nilai-nilai kearifan Islam yang mewakili dari tiga dasar dimensi Agama Islam yang juga mewakili tiga tingkatan pencapaian kedudukan seorang muslim.

\section{Bentuk Denah}

Struktur denah Masjid Agung Surakarta bersifat linier dengan prinsip hierarki dalam pola ruangnya. Ruang shalat utama (dalem) adalah ruang yang tertutup, menandakan ruang yang sakral dan bersifat transenden. Ruang serambi (pendopo) adalah ruang terbuka dan bersifat profan. Tambahan pawestren sebagai ruang khusus shalat wanita .

Bentuk denah menggambarkan wujud ruang masjid yang berdampak pada aktivitas yang terjadi di dalamnya. Denah ruang utama adalah ruang yang paling sakral dan memiliki konsep kosmologi Jawa pada elemen ruang, soko guru hingga atapnya. Sehingga aktivitas yang ada di dalam ruang utama merupakan aktivitas yang paling mendasar yaitu ibadah shalat. Sedangkan pada ruang serambi yang merupakan ruang profan dan terbuka lebih fleksibel dengan ragam aktivitas yang lebih variatif.

Bentuk denah masjid mewakili konsepsi wujud ruang arsitektur Jawa yaitu dalem dan pendopo. Pada dasarnya bentuk denah ruang utama tidak memiliki orientasi kecuali setelah dibentuk ruang kecil yaitu mihrab yang menjadi penanda orientasi ke arah kiblat. Bentuk denah juga dipengaruhi oleh jarak antar keempat soko guru masjid yang menjadi dasar terbentuknya masjid.

\section{Soko Guru}

Bangunan utama masjid terdapat soko- soko yang terdiri dari pilar utama, yaitu empat soko guru, 12 buah saka penanggap di sekeliling soko guru, dan 16 buah tiang semu di sisi pinggir bangunan utama.

Keempat soko guru berbentuk silinder dari bahan kayu terletak pada poros ruang utama dan sebagai penopang atap tajug bagian puncak. Soko guru merupakan elemen struktur yang sangat penting karena memiliki keterkaitan langsung dengan konsep kosmologi Jawa dengan keempat pilarnya membentuk pajupat/ mancapat dan menjadi dasar awal dibentuknya masjid. Hal yang menjadi ciri khas soko guru adalah posisi dan material yang digunakan berbeda dengan soko-soko lainnya, sehingga keempat soko guru dengan bentuk, ukuran, bahan, dan fungsi yang sama menjadi elemen yang sangat berpengaruh dalam pembentukan bangunan utama masjid. Soko guru menciptakan poros/ inti bangunan induk dimana poros tersebut berkaitan erat dengan unsur vertikal yang diwujudkan dengan atap tajugnya terutama tajug paling atas yang secara langsung ditopang oleh keempat soko guru tersebut (Gambar 8 dan 9).

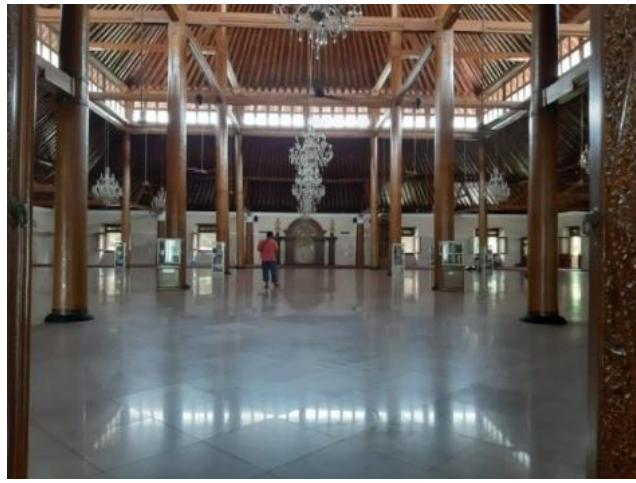

Gambar 8. Soko Guru Masjid Agung Surakarta (Sumber: Fakultas Teknik UNS, 2004)

\section{Ruang Utama ( Ndalem)}

Masjid Agung Surakarta memiliki ruang utama (dalem) yang menjadi pusat bangunan keseluruhan masjid. Secara vertikal, poros ruang utama masjid menyatu dengan empat soko guru yang memberikan nilai-nilai spiritualitas. Ruang dalem dengan atap tajug mewakili aspek transenden (habblumminallah), ruang pendopo dengan atap limasan mewakili aspek imanen (hablumminannas).

Ruang utama Masjid Agung Surakarta menghadirkan makna spasial yang sangat kuat, yang menggambarkan adanya keseimbangan dan keharmonisan lahir dan batin, pencapaian kebaikan 
hidup dunia dan akhirat. Semua termuat sebagai nilainilai religiusitas yang terpancar sebagai penanda ruang yang sakral sekaligus berperan sebagai sense of place dari bangunan masjid secara keseluruhan (Gambar 10).
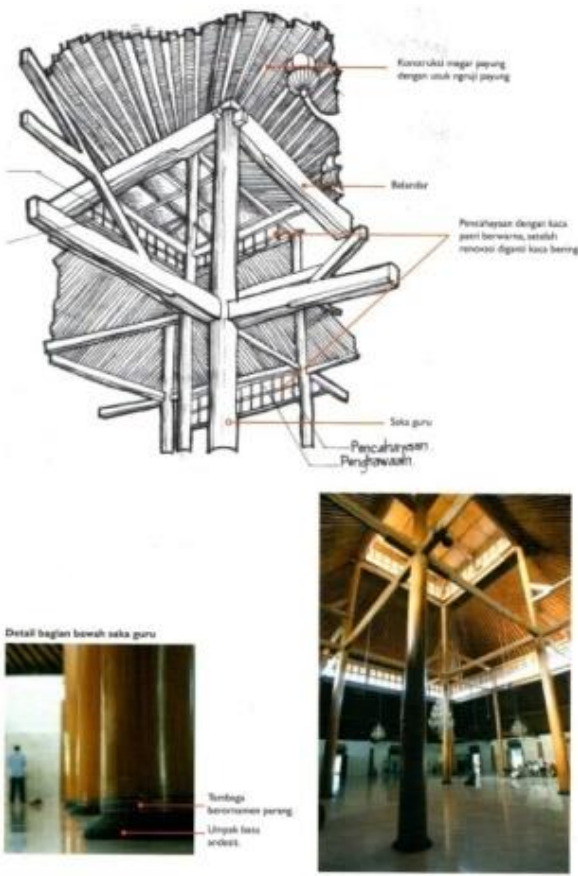

Gambar 9. Detail Soko Guru Masjid Agung Surakarta (Sumber: Fakultas Teknik UNS, 2004)

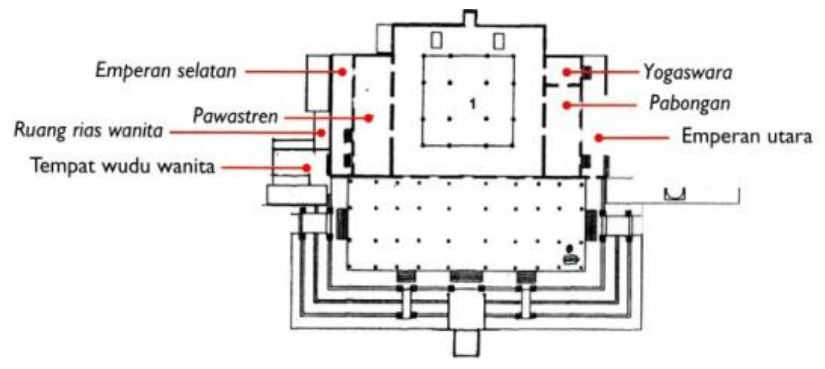

Gambar 10. Denah Masjid Agung Surakarta (Sumber: Fakultas Teknik UNS, 2004)

\section{Mihrab}

Mihrab adalah tempat berdirinya imam saat melaksanakan shalat, yaitu sebuah ruang dengan bidang dinding berupa ceruk yang menjorok ke dalam sehingga seperti membentuk ruangan tanpa pintu, namun menyatu dengan ruang utama masjid. Mihrab berfungsi selain buat tempat imam shalat juga sebagai penanda arah orientasi masjid ke kiblat yang merupakan arah orientasi shalat (Gambar 11).

\section{Serambi}

Serambi Masjid Agung Surakarta berbentuk empat persegi panjang dengan ukuran 20,80 m x 52,80 m. Serambi masjid dibangun saat masa Sultan Pakubuwana XII berkuasa. Konstruksi serambi

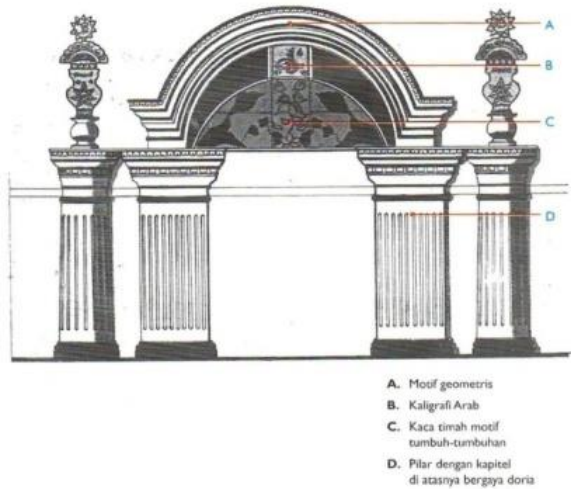

Gambar 11. Mihrab Masjid Agung Surakarta (Sumber: Fakultas Teknik UNS, 2004)

dinamakan "limasan klabang nyander" yang berarti atap limasan memanjang dengan pengeret lebih dari empat buah. Konstruksi atap ini menyerupai atap pendapa bangunan rumah tinggal yang dibangun dengan tata letak arsitektur Jawa yang telah mendapat pengaruh kolonial. Atap serambi ditopang 40 tiang, di mana 8 pasang tiang menopang atap tingkat teratas. Sisanya menopang bagian pinggir. Pada bagian serambi, terdapat bedug yang diberi nama Kiai Wahyu Tengara dan kentongan kayu jati yang memiliki panjang $265 \mathrm{~cm}$.

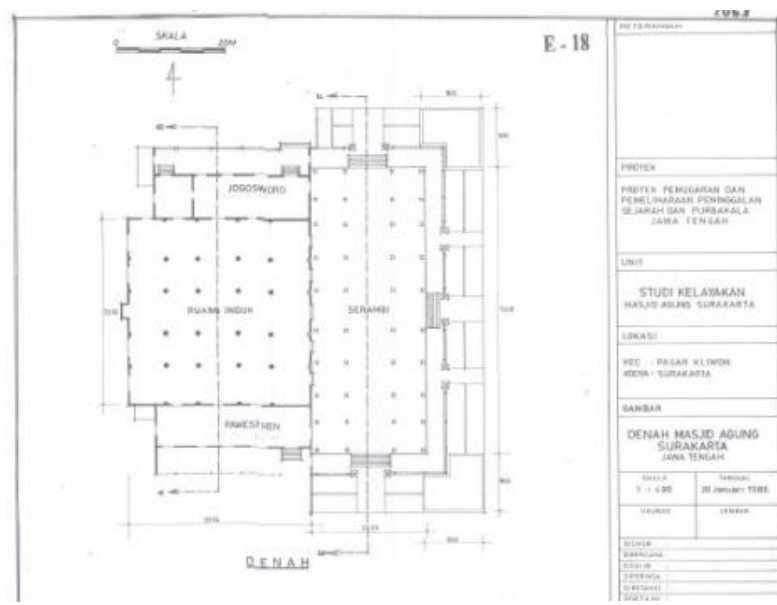

Gambar 12. Denah Masjid Agung Surakarta (Sumber: Fakultas Teknik UNS, 2004)

\section{Gerbang Utama}

Fungsi Gapura ini adalah sebagai gerbang utama yang mempertemukan kompleks Masjid Agung Surakarta dengan kawasan Alun-alun Keraton Surakarta. Pintu Gerbang Utama bergaya Persia hasil perombakan Sultan Pakubuwana $X$. Pada gapura terdapat 3 pintu, di mana setiap pintu terdapat beberapa simbol. Pada pintu tengah terdapat relief dari kayu yang menggambarkan bumi, bulan, matahari dan bintang dengan mahkota raja di atasnya. Sementara itu pintu pengapit sisi utara dan selatan terdapat panil kayu berhias relief Arab (Gambar 13). 


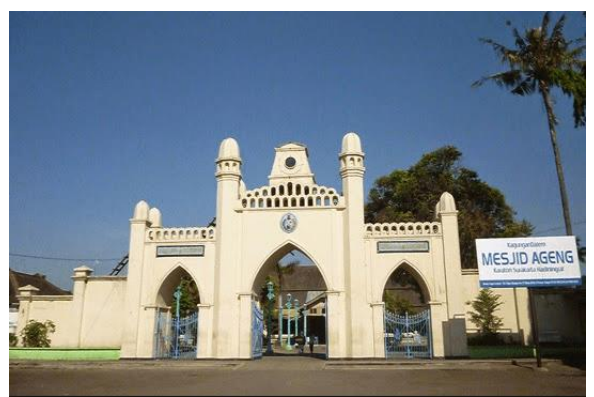

Gambar 13. Gerbang Utama Masjid Agung Surakarta

(Sumber: Dokumentasi penulis, 2019)

\section{KESIMPULAN}

Berdasarkan teori masjid Jawa menurut Pijper (1947) yang menyatakan bahwa masjid di Jawa memiliki beberapa karakteristik sebagai berikut: mempunyai bentuk persegi, (2) tidak disangga oleh tiang-tiang pada dasar bangunannya. (3) Memiliki atap tumpang dua sampai lima tingkatan. (4) Memiliki perluasan ruang pada sisi barat atau barat laut, yang digunakan sebagai mihrab. (5) Memiliki serambi Masjid pada bagian depan atau samping. (6) Halaman sekeliling masjid tertutup oleh dindingdinding dengan hanya satu pintu masuk melalui sebuah gerbang di bagian depan. Masjid Agung memiliki atap tumpang. Masjid Agung juga memiliki bentuk persegi. Mengenai teori yang mengatakan bahwa bangunan masjid di Jawa tidak disangga oleh tiang- tiang pada dasar bangunan, teori tersebut tidak bisa diaplikasikan pada objek yang diteliti karena objek masjid yang diteliti memiliki tiang atau yang disebut soko guru sebagai penyangga. Masjid Agung Surakarta memiliki serambi pada bagian depan atau samping masjid.Halaman sekeliling masjid memang tertutup oleh dinding tetapi tidak hanya memiliki satu pintu masuk.

Menurut Budi (2006, 220:231), ada tiga elemen dalam Masjid Jawa, yaitu: (1) Ruang shalat sebagai kebutuhan mutlak yang digunakan jemaah untuk melakukan ibadah. (2) Mihrab merupakan ruang imam memimpin shalat, sekaligus sebagai penunjuk arah kiblat. (3) Atap dan struktur Masjid Jawa memiliki bentuk tumpang yang khas dimana pada bagian bawah terdapat struktur (sokoguru) yang menyangganya. Masjid Agung Surakarta memiliki tiga elemen yang disebutkan yaitu ruang solat, mihrab, dan atap serta struktur berbentuk tumpang dan bagian bawah terdapat sokoguru.

De Graaf mengajukan teori bahwa prototipe bangunan masjid Indonesia tidak berdasarkan atas bangunan yang ada di Indonesia, tetapi dari bentuk masjid-masjid yang ada di daerah Gujarat (India). Hal ini tampak pada menara yang terdapat pada Masjid Agung.

\section{DAFTAR PUSTAKA}

Arismunandar A., Brommer B., Davison J., Dominez G., Dumarcay J., Forth G., Fox J., Germain S., Gill R., Goes B.V. D., Miksic J., Murtiyoso S., O'neil H. 2002. Indonesian Heritage. Jakarta: PT Widyarta

Budi, Bambang Setia. 2006. A Study on the History and Development of Javanese Mosque part 3: Typology of The Plan and Structure of The Javanese Mosque and Its Distribution. Journal of Asian Architecture and Building Engineering

Dakung S. 1982. Arsitektur Tradisional Yogyakarta. Dokumentasi Kebudayaan Daerah.

H.J.de Graaf, 1963, "The Origin of Javanese Mosque" Journal of Southeast Asian History, IV

Macrus. 2008. Simbol-Simbol Sosial Kebudayaan Jawa, Hindu dan Islam yang direpresentasikan dalam artefak Masjid Agung Surakarta. Tesis. Universitas Sebelas Maret Surakarta

Mangunwijaya, Y. 1992. Wastu Citra. Jakarta: PT. Gramedia Pustaka Utama

H. Pijper 1947, The Minaret in Java, in India Antiqua

Setiawan, Agus. 2010. Ornamen Masjid Mantingan Jepara Jawa Tengah. Jurnal Dewa Ruci vol 6 no 2.

Sugiyono. 2017. Metode Penelitian Kuantitatif, Kualitatif, dan R\&D. Alfabeta, CV. Bandung :

Sukmadinata, Nana Syaodih. 2009, Metode penelitian pendidikan, Bandung: Remaja Rosdakarya 